\title{
Characteristics of Consonant Discrimination and Articulation in Patients with Broca's Aphasia
}

\author{
Hyun Jin Lee ${ }^{1,2}$, Seong Hee Choi ${ }^{2}$, Chul-Hee Choi $^{2}$ \\ 'Department of Rehabilitation Medicine, Dankook University Hospital, Speech-Language Therapy Clinic, Cheonan, Korea \\ ${ }^{2}$ Department of Audiology \& Speech-Language Pathology, Research Institute of Biomimetic Sensory Control, and Catholic Hearing Voice Speech Center, \\ Daegu Catholic University, Gyeongsan, Korea
}

\section{브로카 실어증 환자의 자음변별과 조음 특성 이현진 ${ }^{1,2} \cdot$ 최성희 ${ }^{2} \cdot$ 최철희 ${ }^{2}$}

단국대학교병원 재활의학과 언어치료실 ${ }^{1}$, 대구가톨릭대학교 바이오메디대학 언어청각치료학과, 생체모방감각제어연구소, 가톨릭 청각음성언어센터 ${ }^{2}$

\begin{abstract}
Purpose: Generally, Broca's aphasia, also known as motor aphasia is characterized by non-fluent speech and poor articulation. The current study compared consonant discrimination, phonetic representation and voice onset time (VOT) between patients with Broca's aphasia and normal people to investigate speech motor control and articulatory characteristics in patients with Broca's aphasia. Methods: Twenty patients with Broca's aphasia and age and gender matched twenty normal speakers participated in the present study. Naming task in Korean Western Aphasia Battery-Revised, repetition task, and nonsyllabic phoneme discrimination tasks were used to explore phonetic representation ability and auditory phoneme discrimination in patients with Broca's aphasia. In addition, a total of nine-vowelconsonant-vowel syllable stimuli [3 (phonation type) x 3 (place of articulation)] were used to test VOT. The consonant discrimination and production test were analyzed by manner of articulation (stop, fricative, affricate), place of articulation (bilabial, alveolar, palatal, velar), and phonatory type (lenis, fortis, aspirated). Results: For consonant discrimination, no significant difference between normal and Broca's aphasia group was found. Significant articulatory breakdown, however, was observed in Broca's aphasia compared to normal control in nonsyllable repetition task as well as naming task in all place and manner of articulation and phonatory type. This study demonstrated significant differences between normal and Broca's aphasia groups in VOT according to phonatory type, indicating significant longer VOT in fortis than that of control whereas no significant difference in VOT regarding place of articulation between two groups. Conclusion: Although consonant discrimination ability was preserved, individuals with Broca's aphasia demonstrated poor speech motor control and articulation performance.
\end{abstract}

Key Words: Broca's aphasia, Speech motor control, Consonant discrimination, Phonetic representation, Articulation.

Received: February 15, 2018 / Revised: April 16, 2018 / Accepted: April 18, 2018

Correspondence: Seong Hee Choi, Department of Audiology \& Speech-Language Pathology, Research Institute of Biomimetic Sensory Control, and Catholic Hearing Voice Speech Center, Daegu Catholic University, 13-13 Hayang-ro, Hayang-up, Gyeongsan 38430, Korea

Tel: +82-53-850-2542 / Fax: +82-53-359-0780 / E-mail: shgrace@cu.ac.kr

\section{INTRODUCTION}

우리나라 3대 사망 원인에는 암, 심장 질환, 뇌혈관 질환이 속한다. 그중 뇌혈관 질환으로 인한 사망률은 우리나라 인구 1 만 명당 4.82명이 해당되며, 단일 장기 질환으로는 가장 높은 사망률을 보인다. 뇌혈관 질환의 원인으로는 고혈압, 당뇨, 고지 혈증, 흡연, 비만, 스트레스 등이 있으며, 70대에서 발병률이 가 장 크다(Korea National Statistical Office, 2016). 우리나라의 전체 인구 중 $13 \%$ 가 노인으로, 2030년에는 유엔 기준에 따라
전체 인구 중 65 세 이상 고령인구 비율이 $20 \%$ 이상인 초고령 화 사회에 진입하게 될 것이다. 그러므로 사회적으로 노년층에 대한 관심이 높아지고, 그에 따라 뇌혈관 질환에 대한 치료와 예후에 대한 관심도 꾸준히 증가할 것이다. 뇌혈관 질환으로 인 해 신체적, 사회적, 심리적, 언어적으로 어려움을 겪는다. 특히, 언어적으로 표현에 어려움이 생길 경우 답답함, 좌절감 등의 심 리적인 문제가 유발될 수 있다.

실어증 진단을 받은 대부분의 성인들은 뇌출혈, 뇌경색, 교통 사고나 낙상으로 인한 뇌 손상으로 인해 의사소통에 필요한 언 
어적인 영역에 손상을 받은 경우가 많다. 즉, 실어증은 후천적인 대뇌 손상으로 인해 유창성(fluency), 이해능력(comprehension), 따라 말하기(repetition), 이름 대기(naming) 과제에서 수 행 저하를 보여, 언어(language)와 말(speech) 기전에 손상을 받은 경우를 말한다(McNeil, 1984).

한편, 브로카 실어증(Broca’s aphasia)은 피질하백질의 뇌실 주변을 포함한 전두엽 측면, 실비우스열 위쪽, 중심구 앞쪽에 손상을 입게 되어 언어능력이 손상되는 유형으로, 상대적으로 표현 언어에서 어려움을 보인다(Kim, 2012). 브로카 실어증 환 자는 이해능력은 잘 보존되어 있는 반면 비유창한 구어와 부 족한 조음능력을 가지고 있기 때문에 표현성 혹은 운동성 언어 장애로 잘 알려져 있다(McNeil, 1984). 또한 자음과 모음의 왜 곡과 같은 조음 오류가 빈번한 조음 붕괴 현상이 잘 일어난다. 아울러 브로카 실어증 환자들은 자신이 말하거나 쓰는 것보다 듣거나 이해하는 것을 더 잘하는 것으로 알려져 있으나, 일반적 으로 듣고 이해하는 능력도 모두 약간의 장애가 있는 것으로 보고되고 있다.

브로카 실어증 환자는 신경계 손상으로 인해 조음에 관여하 는 말 운동기관에 제한을 받게 되어 비일관적인 조음 오류로 인해 조음장애를 동반한다(Banich \& Compton, 2014). 이러한 이유로 말 산출 시 발화의 길이가 짧고, 단어를 표현하는 데 의 의를 두어(Davis, 2000), 문장 구조가 단순화된 '전보식 구어'를 주로 사용한다. 복잡한 음운 구조는 단어 내 분절음의 산출을 어렵게 하여 전반적인 조음 산출에 영향을 준다(Kim et al., 2002). 말장애를 동반한 환자들은 음운, 음성학적으로 복잡한 단어를 산출할 경우, 말 운동 프로그래밍을 계획하고 조절하는 데 어려움이 있기 때문에 조음 오류가 나타날 수밖에 없게 된다.

실어증 환자의 음운 오류 패턴을 살펴보면 생략, 대치, 첨가 를 주로 보이고, 그중에서도 대치 현상을 가장 많이 보인다 (Popovici \& Voinescu, 1991). 브로카 실어증 환자들의 오류를 살펴보면 동사보다 명사 산출 시 착어가 상대적으로 적게 나타 나며(Bae, 2005; Magnúsdóttir \& Thráinsson, 1990; Stark \& Dressler, 1990), 의미 착어보다 음소 착어가 빈번히 발생한다 (Bae, 2005; Huber et al., 1997).

말소리는 변별 자질에 의해 구분되는데, 실어증 환자들은 말 소리의 음소표상장애를 가지므로 음소의 변별적 자질들을 지 각하거나 산출하는 데 어려움을 보이며 이러한 특성들이 말 산 출 오류와 언어 이해에 모두 영향을 미치는 것으로 보고되었다 (Miceli et al., 1980). 예를 들면, 한국어의 경우 발성 유형에 따 라 평음, 경음, 격음으로 구분되는데 /바/, /빠/, /파/는 조음 위 치와 방법은 같고, 발성 유형만 서로 다른 음소로 이루어진 최 소대립쌍을 이룬다. 국내에서는 조음음운 장애아동과 일반아 동을 비교하여 음운표상의 질과 음운표상 부호화 능력을 비교
한 연구가 있었으나(Kim \& Ha, 2014), 아직까지 실어증 환자를 대상으로 음운표상능력을 살펴본 연구는 없었다.

한편, 유창성 실어증 환자군과 비유창성 실어증 환자군을 대 상으로 한 국외 발성개시시작시간(Voice Onset Time, VOT)에 관한 연구들에서는 비유창성 실어증 환자군에서 $\mathrm{VOT}$ 가 대조 군과 비교했을 때 길게 나타났다고 한다(Baum et al., 1990; Ryalls et al., 1995; Shewan et al., 1984). 유창성 실어증 환자의 VOT는 느리게 말할 때보다 빠르게 말할 때 짧게 나타났으며 (Baum \& Ryan, 1993), 브로카 실어증 환자의 VOT는 베르니케 실 어증 환자와 비교했을 때 더 길게 나타났다(Gndour \& Dardarananda, 1984).

현재까지 브로카 실어증 환자를 대상으로 한 국내 연구를 살 펴보면, 이해 영역과 구어 유창성에 대한 연구가 대부분이며 (Hwang, 2002; Kim et al., 2004), 청각적으로 들어온 정보를 산출하는 음소지각능력이나 조음산출 특성이나 음운처리능력 에 대한 연구는 상대적으로 적은 편이다.

따라서 본 연구에서는 브로카 실어증 환자를 대상으로 음소 변별력, 음소 대치나 착어와 같은 음소표상능력을 살펴봄으로 써 비유창성 브로카 실어증 환자들의 말 처리 과정 기전에 대 해 살펴보고자 한다. 이를 위해 무의미음절 수준에서 청각적 음소변별능력과 무의미음절 따라 말하기나 단어 수준에서 이 름 대기 시 나타나는 조음 오류 특성을 통해 음소표상 부호화 능력을 정상군과 비교하여 브로카 실어증 환자의 조음음운 특 성을 살펴보고자 한다. 아울러, 조음과 관련된 성대 진동 움직임 에 대한 음향학적 특성을 살펴보기 위하여 vowel-consonantvowel (VCV) 음절 수준에서 VOT를 측정하여 정상군과 차이 를 보이는지에 대해 알아보고자 한다.

\section{MATERIALS AND METHODS}

\section{연구 대상}

본 연구는 대구가톨릭대학교 생명윤리위원회의 승낙을 받아 진행되었다(CUIRB-2015-0070).

본 연구는 정상 성인 10 명과 브로카 실어증 환자 10 명을 대상 으로 실시하였다. 브로카 실어증 환자는 부산 소재 종합병원 및 재활병원의 재활의학과에 입원 또는 내원하고 있는 환자 중에 서 모집하였으며, 정상 성인은 부산에 거주하고 있는 자를 대상 으로 모집하였다. 대상자의 각 집단별 선정기준은 다음과 같다.

실어증 환자는 1) 후천적인 좌뇌 손상으로 인해 언어장애를 보 이는 자, 2) 한국판 웨스턴 실어증 검사(Korean Western Aphasia Battery-Revised, K-WAB-R) (Kim \& Na, 2012) 결과, 브 로카 실어증으로 분류된 자(심한 말실행증을 동반한 브로카 실 어증 환자 제외), 3) 발병 이전에 뇌 손상 및 기타 신경학적 질환 
이 없었다고 보고된 환자, 4) 발병 후 최소 1 개월이 경과한 환자 (Yorkston \& Beukelman, 1980), 5) 이름 대기 수행이 전혀 불 가능한 환자는 제외하기 위해 $\mathrm{K}-\mathrm{WAB}-\mathrm{R}$ 의 이름 대기 점수가 2 점 이상(10점 만점)인 환자, 6) 연령과 교육 수준 차이가 수행에 미치는 영향을 최소화하기 위해 75세 이하이면서 최소한 초등 학교 졸업 이상의 학력을 갖춘 성인을 대상으로 하였다(Kang et al., 2000; Tomer \& Levin, 1993)

정상 성인은 1) 실어증 환자 집단과 평균 연령 및 평균 교육 연수가 일치하는 자, 2) 언어 및 신경학적 손상, 병력이 보고되 지 않는 자를 대상으로 하였다.

모든 대상자는 과제 수행을 위해 시력과 청력에 문제가 없는 자로 선정하였으며, 모두 오른손잡이를 대상으로 하였다. 대상 자 정보는 Table 1과 2에 제시하였다.

\section{실험 도구 및 절차}

\section{음소 변별 과제}

정상군과 브로카 실어증 환자군 간 청각적 음소 변별 특성에 대해 알아보기 위해 Kwon(2004)의 연구에 사용되었던 자음 변별 검사지를 이용하였으며, 검사 문항 중 일부를 수정하여 사
용하였다(Appendix 1), 녹음은 연구자가 소음이 통제된 조용한 방에서 단일 지향성 마이크(SURE MX183-X; Woollim Sound Inc., Seoul, Korea)와 디지털레코더(EDI-ROL R-05HR)를 이 용하여 녹음하였다. 이후 소음이 통제된 조용한 방에서 두 가 지의 말소리를 듣고, 대상자에게 정/오 판정을 하도록 유도하였 다. 수행력은 전체 40 개 문항 중 정반응한 문항의 정반응률을 $\%$ 로 계산하였다.

\section{무의미음절 수준에서의 따라 말하기 과제}

정상군과 브로카 실어증 환자군 간 무의미음절 수준에서 음 소표상 부호화 능력을 살펴보기 위하여 음소 변별 과제에서 사 용된 음절 목록을 이용하여 무의미음절 수준에서 따라 말하기 를 실시하였다. 브로카 실어증 환자이므로 음절 길이의 영향을 최소화하기 위하여 음절은 최대 2개 음절로 제한하였다. 40개 문항 내 2 개의 음절이 포함되어 있으므로 총 80 개의 음절로 이 루어져 있으며, 발성 유형에 따라 평음, 경음, 격음, 조음 방법에 따라 파열음, 마찰음, 파찰음, 비음, 설측음, 조음 위치에 따라 양순음, 치조음, 경구개음, 연구개음, 성문음으로 이루어져 있 다. $\mathrm{CV}$ 형태로 이루어진 두 소리를 대상자에게 들려준 후, 그대 로 따라 말하도록 유도하였다. 따라 말하기 과제 시 기록지에

Table 1. Information of normal adults

\begin{tabular}{|c|c|c|c|c|c|c|c|}
\hline & Age & Gender & $\mathrm{EY}$ & Group & POT (month) & K-WAB naming score & $\mathrm{AQ}$ \\
\hline N1 & 56 & $\mathrm{M}$ & 12 & Normal & - & - & - \\
\hline $\mathrm{N} 2$ & 73 & M & 6 & Normal & - & - & - \\
\hline N3 & 55 & M & 14 & Normal & - & - & - \\
\hline N4 & 49 & $\mathrm{M}$ & 6 & Normal & - & - & - \\
\hline N5 & 53 & $\mathrm{M}$ & 16 & Normal & - & - & - \\
\hline N6 & 54 & M & 12 & Normal & - & - & - \\
\hline N7 & 61 & $\mathrm{M}$ & 9 & Normal & - & - & - \\
\hline N8 & 52 & $\mathrm{M}$ & 18 & Normal & - & - & - \\
\hline N9 & 52 & $\mathrm{~F}$ & 14 & Normal & - & - & - \\
\hline N10 & 66 & M & 12 & Normal & - & - & - \\
\hline
\end{tabular}

EY: education year, POT: post-onset time, K-WAB: Korean Western Aphasia Battery, AQ: Aphasia Quotient, N: normal

Table 2. Information of patients in Broca's aphasia

\begin{tabular}{|c|c|c|c|c|c|c|c|}
\hline & Age & Gender & EY & Group & POT & K-WAB naming score & $\mathrm{AQ}$ \\
\hline B1 & 50 & M & 9 & Broca & 18 & 6.3 & 59.4 \\
\hline B2 & 61 & M & 12 & Broca & 8 & 6.8 & 51.6 \\
\hline B3 & 48 & M & 16 & Broca & 12 & 6.5 & 68.0 \\
\hline B4 & 64 & M & 18 & Broca & 30 & 7.7 & 58.8 \\
\hline B5 & 59 & M & 12 & Broca & 37 & 3.9 & 31.3 \\
\hline B6 & 49 & M & 9 & Broca & 10 & 5.4 & 43.6 \\
\hline B7 & 52 & $\mathrm{~F}$ & 9 & Broca & 12 & 5.7 & 53.2 \\
\hline B8 & 73 & M & 6 & Broca & 6 & 5.4 & 29.0 \\
\hline B9 & 61 & M & 6 & Broca & 8 & 6.6 & 62.7 \\
\hline B10 & 66 & M & 12 & Broca & 12 & 2.4 & 22.1 \\
\hline
\end{tabular}

EY: education year, POT: post-onset time, K-WAB: Korean Western Aphasia Battery, AQ: Aphasia Quotient, B: Broca 
대상자의 반응을 기록하였으며, 동시에 녹음하였다. 검사 종료 후, 대상자의 오류 특성과 정반응률을 분석하였으며, 수행력은 전체 음소 중 정확히 산출한 음소의 정반응률을 \%로 계산하 였다. 자료의 $20 \%$ 에 해당하는 자료를 1 급 언어재활사가 평정하 였으며 검사자 간 신뢰도는 $100 \%$ 였다.

\section{단어 수준에서 이름 대기 과제}

브로카 실어증 환자의 음소표상 수행력을 알아보기 위해 이 름 대기 과제로 K-WAB 검사도구 내 사물 이름 대기 항목을 사용하였다(Appendix 2). 사물 이름 대기 20문항을 실시하면 서 검사 기록지에 연구대상자의 반응을 기록하였으며, 동시에 녹음하였다. 검사 종료 후 대상자의 오류 특성과 정반응률을 분석하였다. 이름 대기 과제 시 음운 단위는 자음과 모음의 수 행력, 음운 위치는 어두초성, 어중초성, 어말종성 위치에서의 수행력을 측정하였다. 자음 목록은 58개, 모음 목록은 48개이 며, 음운 위치는 어두초성 21 개, 어중초성 10 개, 어말종성은 23 개였다. 수행력은 해당 목표 음소 중 정조음한 음소의 정반응 률을 $\%$ 로 계산하였다. 총 자료의 $20 \%$ 에 해당하는 자료를 1 급 언어재활사가 평정하였으며 검사자 간 신뢰도는 $100 \%$ 였다.

\section{VOT 측정 과제}

발성 개시 특성을 알아보기 위해 검사 자료는 VOT는 파열음 의 조음 위치(양순음, 치조음, 연구개음)와 발성 유형(평음, 경 음, 격음)에 따라 총 9 개( 3 개의 조음 위치 $\times 3$ 개의 발성 유형)의 $\mathrm{VCV}$ (모음 + 자음 + 모음) 음절로 구성하였다. $\mathrm{VCV}$ 음절 문맥 에서 파열음을 /아바/, /아빠/, /아파/, /아다/, /아따/, /아타/, /아 가/, /아까/, /아카/ 산출 시 발성개시시작시간(VOT)을 측정하 여 두 집단 간 차이를 비교하였다. 녹음은 조용한 방에서 실시 하였으며, 비유창성 브로카 실어증은 말 속도가 발성개시시작 시간에 유의미한 차이를 주지 않는다는 선행연구에 근거하여 자연스러운 속도로 읽도록 하였다(Baum \& Ryan, 1993). 녹음 시 표본 추출률은 $44,100 \mathrm{~Hz}$, 양자화는 $16 \mathrm{bit}$ 였다. 발성개시시
작시간 측정은 Praat (ver. 6017, http://www.fon.hum.uva.nl/ $\mathrm{praat} /$ 를 이용하여 VCV 음절에서 파열이 시작되는 곳부터 모 음 발성이 시작하기까지의 시간을 측정하였다. Figure 1은 /아다/ 산출 시 VOT를 분석하는 Praat 에디터 창의 화면 캡쳐 내용이 다. 붉은색으로 표시한 부분이 VCV 음절인 /아다/ 산출 시 /ㄷ/ 음소의 파열이 시작되는 곳부터 모음 /a/ 발성이 시작하기까지 의 시간을 나타내며, 단위는 초(second)로 표시하였다. 음절별 로 3회씩 산출하게 한 뒤 가운데 3개 음절의 VOT를 측정하여 평균을 산출하였다. 총 자료의 $20 \%$ 에 해당하는 자료를 1 급 언 어재활사가 평정하였으며 검사자 간 신뢰도는 발성 유형 및 조 음 위치에 따른 VOT는 각각 $87 \%, 92 \%$ 였다.

\section{통계 분석}

수집된 자료의 통계분석은 SPSS Statistics 19.0 (IBM Corp., Armonk, NY, USA)을 사용하였으며, 기술 통계량으로는 평균 과 표준편차를 구하였으며, 사분위수를 측정하였다. 집단 간 유의한 차이를 알아보기 위해 비모수 통계인 Mann-Whitney U-test를 사용하였다. 따라 말하기 과제에서 브로카 실어증 환 자군 내에서 발성 유형별(평음, 경음, 격음), 조음 방법별(파열음, 마찰음, 파찰음, 비음, 유음), 조음 위치별(양순음, 치조음, 경구 개음, 연구개음, 성문음) 수행력 차이를 알아보기 위해 Kruskal-Wallis 검정을 실시하였다. 또한 실어증 환자군 내에서 이름 대기 과제 시 오류 형태 간(대치, 첨가, 생략), 음운 위치 간(어두 초성, 어중초성, 어말종성) 수행력 차이를 살펴보기 위해 Kruskal-Wallis 검정을 실시하였으며, 유의수준은 95\%였다. 정상군 과 브로카 실어증 집단 간 경음 VOT의 유의성을 살펴보기 위 하여 Mann-Whitney U-test를 실시하였으며, 브로카 실어증 환자의 한국어 자음의 조음 방법, 조음 위치 및 발성 유형에 따 른 파열음의 발성개시시작시간(VOT)을 분석하기 위하여, VOT 의 발성 유형별, 조음 위치별 수행력의 차이도 반복측정분산분 석(repeated measures ANOVA)을 실시하였다. 개체 간 반복측 정분석에 대한 통계검정은 Mauchly의 구형성 검정에 의해 구형

Figure 1. Voice onset time of /ata/ in a patient with Broca's aphasia.

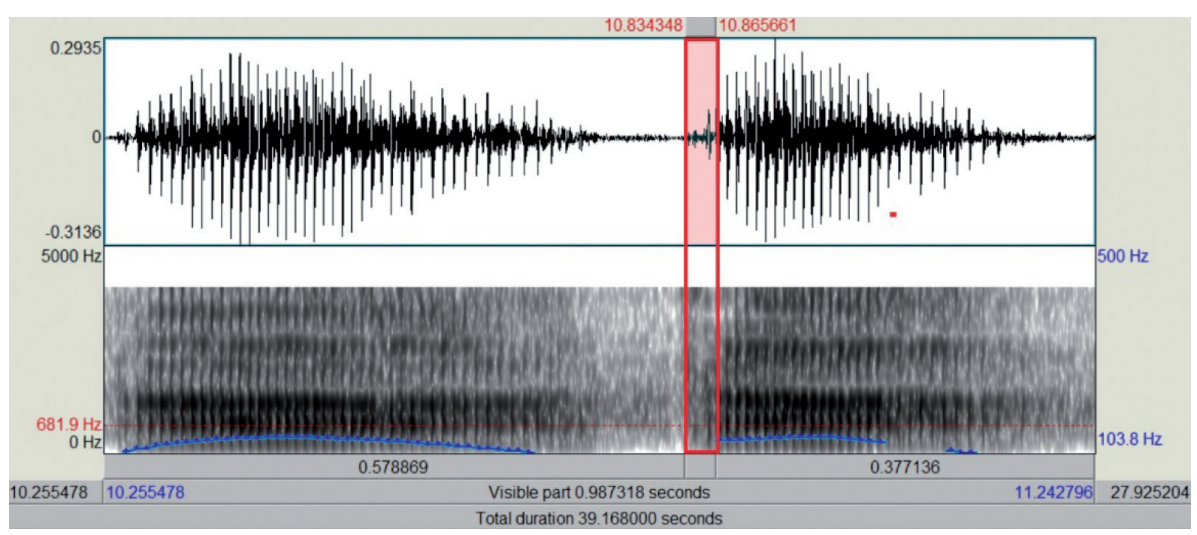


성이 가정된 경우는 구형성 가정값을 사용하였으며, 구형성 가 정을 만족하지 않는 경우는 Greenhouse-Geisser로 수정된 자 유도와 F 값을 보고하였다. 또한 개체 내 효과 검정 결과 통계적 으로 유의미한 경우, 개체 내 대비검정을 실시하여 유의성 검정 을 실시하였다.

\section{RESULTS}

\section{정상군과 브로카 실어증 환자군의 음소 변별 특성}

정상군과 브로카 실어증 환자군의 평균, 표준 편차는 Table 3 과 같다. 두 집단 간 청각적 음소 변별 점수의 유의성을 살펴보 기 위해 Mann-Whitney U-test를 실시한 결과, 정상군과 브로 카 실어증 환자군의 청각적 음소 변별 점수에서는 유의한 차이 를 보이지 않았다( $\mathrm{U}=38.5, p>0.05)$.

\section{무의미음절 수준에서 따라 말하기 시 발성 유형별 음소표상 부호화 능력}

무의미음절 수준에서 따라 말하기 시 발성 유형별 음소표상 부호화 능력에 대한 평균과 표준 편차는 Table 4와 같다. 브로 카 실어증 환자군의 경우, 격음 $(\mathrm{M}=74.11, \mathrm{SD}=32.83)$ 이 가장 높았으며, 격음, 평음, 경음 순이었다.

두 집단 간 평음, 경음, 격음 수행력의 유의성을 살펴보기 위해 Mann-Whitney U-test를 실시한 결과, 정상군과 브로카 실어증 환자군 간 격음 수행력에서만 유의한 차이를 보였다 $(\mathrm{U}=15.0$, $p<0.001)$.

또한 브로카 실어증 환자의 발성 유형별 음소표상 수행력의 유의성을 살펴보기 위해 Krusckal-Wallis 검정을 실시한 결과, 브로카 실어증 환자군에서는 발성 유형 간 수행력에서 유의한 차이를 보이지 않았다 $\left[\chi^{2}(2)=1.654, p=0.437\right]$.

Table 3. Means and SD of phonemic descrimination score between normal and Broca's aphasia

\begin{tabular}{lcr}
\hline Group & Mean & \multicolumn{1}{c}{ SD } \\
\hline Normal & 95.5 & 4.83 \\
Broca & 90.5 & 11.89 \\
\hline
\end{tabular}

SD: standard deviation

Table 4. Means and standard deviation of phonetic representation score between normal and Broca's aphasia in the repetition performance according to phonation types of consonants

\begin{tabular}{lcccc}
\hline & Normal & Broca's & $\chi^{2}$ & $p$ \\
\hline Lenis & $100.0( \pm 0)$ & $71.67( \pm 26.53)$ & 1.654 & 0.437 \\
Fortis & $100.0( \pm 0)$ & $62.23( \pm 26.31)$ & & \\
Aspirated & $100.0( \pm 0)$ & $74.11( \pm 32.83)$ & & \\
\hline
\end{tabular}

무의미음절 수준에서 따라 말하기 시 조음 방법별 음소표상 부호화 능력

무의미음절 수준에서 따라 말하기 시 조음 방법별 음소표상 부호화 능력에 대한 평균과 표준 편차는 Table 5 와 같다.

정상군과 브로카 실어증 환자군 간 조음 방법별 수행력의 유 의성을 살펴보기 위해 Mann-Whitney U-test를 실시한 결과, 두 집단 간 파열음, 마찰음, 파찰음, 비음, 유음 모두 유의한 차이 를 보였다 $(\mathrm{U}=5.0, p<0.001 ; \mathrm{U}=5.0, p<0.001 ; \mathrm{U}=20.0, p<$ 0.01; $\mathrm{U}=10.0, p<0.01 ; \mathrm{U}=18.5, p<0.05)$.

브로카 실어증 환자군 내에서 조음 방법별로 볼 때 브로카 실 어증 환자군은 파열음 $69.7 \pm 29.3 \%$, 마찰음 $70.0 \pm 26.3 \%$, 파 찰음 $73.7 \pm 30.7 \%$, 유음 $60.0 \pm 34.0 \%$, 비음 $76.4 \pm 25.9 \%$ 로 음소표상 부호화 능력은 비음이 가장 수행력이 높았으며, 유음 에서 가장 낮은 수행력을 보였다.

그러나 브로카 실어증 환자의 조음 방법별 수행력의 유의성 을 살펴보기 위해 Krusckal-Wallis 검정을 실시한 결과, 브로 카 실어증 환자군에서는 조음 방법 간 수행력에서 유의한 차이 를 보이지 않았다 $\left[\chi^{2}(4)=2.469, p=0.650\right]$.

\section{무의미음절 수준에서 따라 말하기 시 조음 위치별 음소표상} 부호화 능력

무의미음절 수준에서 따라 말하기 시 조음 위치별 음소표상 부호화 능력에 대한 평균과 표준편차는 Table 6과 같다. 브로 카 실어증 환자군의 조음 위치별 수행력에서는 성문음의 수행 력이 가장 높았으며, 치조음의 수행력이 가장 낮게 나타났다.

Table 5. Means and SD of phonetic representation score between normal and Broca's aphasia in the repetition performance according to all articulation manners

\begin{tabular}{lcccc}
\hline & Normal & Broca’s & $\chi^{2}$ & $p$ \\
\hline Plosives & $100.0( \pm 0)$ & $69.7( \pm 29.3)$ & 2.469 & 0.650 \\
Fricatives & $100.0( \pm 0)$ & $70.0( \pm 26.3)$ & & \\
Affricates & $100.0( \pm 0)$ & $73.7( \pm 30.7)$ & & \\
Nasals & $100.0( \pm 0)$ & $76.4( \pm 25.9)$ & & \\
Liquids & $100.0( \pm 0)$ & $60.0( \pm 34.0)$ & & \\
\hline
\end{tabular}

Mean ( \pm SD). SD: standard deviation

Table 6. Means and SD of phonetic representation score between normal and Broca's aphasia in the repetition performance according to all articulation places

\begin{tabular}{|c|c|c|c|c|}
\hline & Normal & Broca's & $\chi^{2}$ & $p$ \\
\hline Bilabials & $100.0( \pm 0)$ & $73.88( \pm 25.13)$ & 3.667 & 0.453 \\
\hline Alveolars & $100.0( \pm 0)$ & $62.20( \pm 29.25)$ & & \\
\hline Palatals & $100.0( \pm 0)$ & $72.74( \pm 31.76)$ & & \\
\hline Velars & $100.0( \pm 0)$ & $72.00( \pm 33.27)$ & & \\
\hline Glottals & $100.0( \pm 0)$ & $83.32( \pm 30.43)$ & & \\
\hline
\end{tabular}

Mean ( \pm SD). SD: standard deviation 
두 집단 간 조음 위치별 수행력의 유의성을 살펴보기 위해 Mann-Whitney U-test를 실시한 결과, 정상군과 브로카 실어 증 환자군 간 양순음, 치조음, 경구개음, 연구개음, 성문음 수행 력에서 모두 유의한 차이를 보였다 $(\mathrm{U}=5.0, p<0.01 ; \mathrm{U}=0.0$, $p<0.001 ; \mathrm{U}=20.0, p<0.01 ; \mathrm{U}=15.0, p<0.01 ; \mathrm{U}=25.0$, $p<0.05)$.

그러나 브로카 실어증 환자군 내 조음 위치별 수행력의 유의 성을 살펴보기 위해 Kruskal-Wallis 검정을 실시한 결과, 브로 카 실어증 환자군은 조음 위치 간 수행력에서 유의한 차이를 보 이지 않았다 $\left[\chi^{2}(4)=3.667, p=0.453\right]$.

\section{단어 수준에서 이름 대기 과제 시 조음 특성}

\section{정상군과 브로카 실어증 환자군의 음운 오류 특성}

단어 수준에서 이름 대기 시 음운 오류 특성(대치, 첨가, 생 략)에 대한 평균과 표준 편차는 Table 7과 같다. 두 집단 간 대 치 오류 수의 유의성을 살펴보기 위하여 Mann-Whitney Utest를 실시한 결과, 정상군과 브로카 실어증 환자군 간 대치, 첨가, 생략 오류 수 모두 유의미한 차이를 보였다 $(\mathrm{U}=10.0, p$ $<0.01, \mathrm{U}=20.0, p<0.05, \mathrm{U}=10.0, p<0.01)$. 하지만, 브로 카 실어증 환자의 착어 오류 형태 간 수행력의 유의성을 살펴 보기 위해 Kruskal-Wallis 검정을 실시한 결과, 브로카 실어증 환자군은 대치가 가장 많았으나, 착어 오류 형태 간 수행력에 서 유의한 차이를 보이지 않았다 $\left[\chi^{2}(2)=2.500, p=0.287\right]$.

\section{브로카 실어증 환자군의 음운 단위(모음 vs. 자음)에 따른 수행력}

브로카 실어증 환자군 내 음운 단위에 따른 수행력의 평균과 표준편차는 Table 8과 같다. 두 집단 간 자음, 모음 산출 수행 력의 유의성을 살펴보기 위하여 Mann-Whitney U-test를 실 시한 결과, 정상군과 브로카 실어증 환자군 간 자음, 모음 산출

Table 7. Means of paraphasia score (substitution vs. addition vs. omission) between normal and Broca's aphasia in the naming

\begin{tabular}{lcccc}
\hline & Normal & Broca's & $\chi^{2}$ & $p$ \\
\hline Substitution & $0( \pm 0)$ & $5.4( \pm 5.90)$ & 2.500 & 0.287 \\
Addition & $0( \pm 0)$ & $1.5( \pm 1.64)$ & & \\
Omission & $0( \pm 0)$ & $2.3( \pm 2.26)$ & & \\
\hline
\end{tabular}

Mean ( \pm standard deviation)

Table 8. Articulation performances of vowels vs. consonants based on phoneme unit in Broca's aphasia

\begin{tabular}{lclc}
\hline & Normal & \multicolumn{1}{c}{ Broca's } & $p$ \\
\hline Consonants & $100.0( \pm 0)$ & $84.8( \pm 17.22)$ & 0.197 \\
Vowels & $100.0( \pm 0)$ & $93.0( \pm 6.57)$ & \\
\hline
\end{tabular}

Mean ( \pm standard deviation)
수행력 모두 유의미한 차이를 보였다 $(\mathrm{U}=5.0, p<0.001)$.

하지만 브로카 실어증 환자군 내 음운 단위에 따른 수행력을 살펴보기 위하여 Mann-Whitney U 검정을 실시한 결과, 모음 과 자음 간 수행력은 유의한 차이를 보이지 않았다 $(\mathrm{U}=33.000$, $p=0.197)$.

\section{브로카 실어증 환자군의 음운 위치에 따른 수행력}

정상군과 브로카 실어증 환자군의 음운 위치에 따른 평균과 표준 편차는 Table 9와 같다. 정상군과 브로카 실어증 환자군 간 음운 위치에 따른 산출 수행력의 유의성을 살펴보기 위하여 Mann-Whitney U-test를 실시한 결과, 두 집단 간 어두초성, 어중초성, 어말종성 산출 수행력에서 유의미한 차이를 보였다 $(\mathrm{U}=25.0, p<0.05 ; \mathrm{U}=30.0, p<0.05 ; \mathrm{U}=10.0, p<0.01)$.

브로카 실어증 환자군 내에서는 어말종성, 어중초성, 어두초 성 순으로 어말종성의 수행력이 가장 높았다. 하지만 브로카 실어증 환자의 음운 위치별 수행력의 유의성을 살펴보기 위해 Kruskal-Wallis 검정을 실시한 결과, 브로카 실어증 환자군은 음운 위치 간 수행력에서 유의한 차이를 보이지 않았다 $\left[\chi^{2}(2)=\right.$ $1.001, p=0.606]$.

\section{발성개시시작시간(VOT)}

\section{발성 유형별 VOT 비교}

평음에서 정상군과 브로카 실어증 환자군 간 평음 $\mathrm{VOT}$ 의 중위수는 정상군은 $0.1000 \mathrm{~ms}$, 브로카 실어증 환자군은 0.1290 $\mathrm{ms}$ 로 각각 나타났고, 정상군과 브로카 실어증 환자군 간 평음 VOT는 유의미한 차이가 없었다(U = 44.0, $p>0.05)$.

한편, 경음에서 정상군과 브로카 실어증 환자군 간 경음 $\mathrm{VOT}$ 의 중위수는 정상군은 $0.0485 \mathrm{~ms}$, 브로카 실어증 환자군 은 $0.0664 \mathrm{~ms}$ 였으며, 브로카 실어증 환자군이 정상군보다 경음 의 VOT가 유의미하게 긴 것으로 나타났다( $\mathrm{U}=22.0, p<0.05)$. 격음의 경우, 정상군과 브로카 실어증 환자군 간 격음 VOT의 중위수는 정상군은 $0.2925 \mathrm{~ms}$, 브로카 실어증 환자군은 0.2685 $\mathrm{ms}$ 로 나타났으며, 정상군과 브로카 실어증 환자군 간 격음 $\mathrm{VOT}$ 는 유의미한 차이가 없었다(U $=45.0, p<0.05)$.

브로카 실어증 환자군의 발성 유형별 VOT의 평균과 표준 편

Table 9. Alticulation performances of phoneme position, WI, WMI, WF consonant in Broca's aphasia

\begin{tabular}{lcccc}
\hline & Normal & Broca's & $\chi^{2}$ & $p$ \\
\hline WI & $100.0( \pm 0)$ & $84.8( \pm 22.7)$ & 1.001 & 0.606 \\
WMI & $100.0( \pm 0)$ & $86.1( \pm 30.9)$ & & \\
WF & $100.0( \pm 0)$ & $90.9( \pm 7.7)$ & & \\
\hline
\end{tabular}

Mean ( \pm standard deviation). WI: word initial, WMI: word medial initial, WF: word final 
차는 Table 10과 같다. 브로카 실어증 환자군의 평음, 경음, 격 음 수행력은 각각 $0.1277( \pm 0.0435) \mathrm{ms}, 0.0712( \pm 0.0201) \mathrm{ms}$, $0.3031( \pm 0.1123) \mathrm{ms}$ 로 나타났으며, 격음 > 평음 > 경음 순으 로 나타났다. 또한 브로카 실어증 환자군에서 VOT는 발성 유형 간 수행력에서 유의한 차이를 보였으며 $[\mathrm{F}(2,18)=30.363, p=$ 0.000], 대응별 비교 결과, 경음은 격음과 평음 모두 유의한 차 이를 보였다 $(p=0.000)$.

\section{조음 위치별 VOT 비교}

정상군과 브로카 실어증 환자군 간 양순음 VOT의 중위수를 살펴본 결과, 중위수는 정상군은 $0.1370 \mathrm{~ms}$, 브로카 실어증 환 자군은 $0.1155 \mathrm{~ms}$ 로 나타났으며, 정상군과 브로카 실어증 환자 군 간 양순음 $\mathrm{VOT}$ 는 유의미한 차이가 없었다 $(\mathrm{U}=40.5, p>$ 0.05).

정상군과 브로카 실어증 환자군 간 치조음 $\mathrm{VOT}$ 의 중위수는 정상군은 $0.1305 \mathrm{~ms}$, 브로카 실어증 환자군은 $0.1405 \mathrm{~ms}$ 로 나 타났으며, 정상군과 브로카 실어증 환자군 간 치조음 $\mathrm{VOT}$ 는 유의미한 차이가 없었다 $(\mathrm{U}=36.0, p>0.05)$.

정상군과 브로카 실어증 환자군 간 연구개음 $\mathrm{VOT}$ 의 중위수 는 정상군은 $0.1770 \mathrm{~ms}$, 브로카 실어증 환자군은 $0.2310 \mathrm{~ms}$ 로 나타났으며, 정상군과 브로카 실어증 환자군 간 연구개음 $\mathrm{VOT}$ 는 유의미한 차이가 없었다 $(\mathrm{U}=30.0, p>0.05)$.

브로카 실어증 환자군의 조음 위치별 VOT 평균과 표준 편 차는 양순음 $0.0469( \pm 0.0379) \mathrm{ms}$, 치조음 $0.0431( \pm 0.0308)$ $\mathrm{ms}$, 연구개음 0.0605( \pm 0.0412) ms로 나타났으며, 연구개음, 양순음, 치조음 순으로 치조음의 VOT가 가장 짧았으며, 브로 카 실어증 환자군에서 VOT는 조음 위치 간 수행력에서 유의 한 차이를 보였다 $[\mathrm{F}(2,58)=15.10, p=0.000]$. 대응별 비교 결 과, 연구개음의 VOT는 양순음의 VOT와 유의한 차이를 보였으 며 $(p=0.002)$, 치조음의 VOT와도 유의한 차이를 나타내었다

Table 10. Mean and SD of voice onset time according to phonation type in Broca's aphasia group

\begin{tabular}{lccc}
\hline & Mean $(\mathrm{msec})$ & SD & F \\
\hline Lenis & 0.1277 & 0.0435 & $30.363^{*}$ \\
Fortis & 0.0712 & 0.0201 & \\
Aspirated & 0.3031 & 0.1123 & \\
\hline
\end{tabular}

${ }^{*} p<0.001$. SD: standard deviation

Table 11. Mean and SD of voice onset time according to place of articulation in Broca's aphasia group

\begin{tabular}{lccc}
\hline & Mean $(\mathrm{msec})$ & SD & F \\
\hline Bilabials & 0.0469 & 0.0379 & $15.10^{*}$ \\
Alveolars & 0.0431 & 0.0308 & \\
Velars & 0.0605 & 0.0412 & \\
\hline
\end{tabular}

${ }^{*} p<0.001$. SD: standard deviation $(p=0.000)($ Table 11).

\section{DISCUSSIONS}

본 연구는 정상 성인 10 명, 브로카 실어증 환자 10 명, 총 20명 을 대상으로 정상군과 브로카 실어증 환자군 간 말소리 지각변 별능력과 말 산출 특성을 살펴보기 위하여 말지각 변별검사와 무의미음절 수준, 단어 수준에서 말 산출능력을 조사하여 어 떠한 특성을 보이는지 알아보았다.

\section{청각적 변별 특성}

정상군과 브로카 실어증 환자군 간 청각적 음소 변별 수행력 을 분석한 결과, 정상군 $95.5( \pm 4.83) \%$, 브로카 실어증 환자군 $90.5( \pm 11.89) \%$ 로 나타났으며, 통계적으로 유의미한 차이를 보 이지 않았다 $(p>0.05)$. Miceli et al.(1980)은 실어증 환자들이 음소 산출뿐만 아니라 음소 지각에도 어려움을 보인다고 보고 하였다. Miceli et al.의 연구에서는 CCVC 음절로 이루어진 단 어를 이용하여 발성 유형별과 조음 위치별로 나누어 분석하였 다. 그러나 한국어의 음절 구조 특성상 한 음절 내에서 연속된 자음군을 허용하지 않는 점을 고려하여, 본 연구에서는 $\mathrm{CV}$ 음 절 2개를 들려주었으며, 분석 시 발성 유형별, 조음 위치별로 나누지 않았다. 본 연구에서는 정상군과 브로카 실어증 환자군 간 청각적 음소 변별 점수에 유의미한 차이를 보이지 않았으며, 브로카 실어증 환자군은 청각적 음소변별능력은 정상적으로 유지됨을 시사하였다.

\section{무의미음절 수준에서 따라 말하기 과제 시 조음 특성}

무의미음절 수준에서의 따라 말하기 수행 결과, 발성 유형별 로 나누었을 때 정상군은 모두 $100 \%$ 로 높은 수행력을 보였으 며, 브로카 실어증 환자군의 수행력은 평음 71.1 $( \pm 26.5) \%$, 경 음 62.2( \pm 26.3$) \%$, 격음 74.1( \pm 32.8$) \%$ 로 나타났다. 경음, 평음, 격음 순으로 어려움을 보였으며, 모두 통계적으로 유의미한 차 이를 보였다 $(p<0.001)$. 하지만, 브로카 실어증 환자군 내에서 는 발성 유형 간 음소표상 부호화 수행력에서 유의한 차이를 보 이지 않았다.

조음 방법별 수행력에서는 정상군은 모두 $100 \%$ 로 높은 수 행력을 보였다. 하지만 브로카 실어증 환자군의 수행력은 파열 음 69.7 $( \pm 29.3) \%$, 마찰음 70.0( \pm 29.6$) \%$, 파찰음 73.7 \pm $30.7) \%$, 비음 76.4( \pm 25.9$) \%$, 설측음 60.0( \pm 34.0$) \%$ 로 나타났 다. 조음 방법별 수행력 차이에서는 비음의 산출 정확도가 가장 높았으며, 파찰음, 마찰음, 파열음, 설측음 순으로 설측음이 가 장 낮은 산출 정확도를 보였으며, 표준편차 또한 설측음에서 가 장 컸다. 조음 방법별 수행력에서는 모두 정상군과 브로카 실어 
증 환자군 간 유의미한 차이가 있다고 나타났다 $(p<0.05)$. 하 지만, 브로카 실어증 환자군 내에서는 조음 방법 간 음소표상 부호화 수행력에서 유의한 차이를 보이지 않았다.

조음 위치별 수행력에서는 정상군은 모두 $100 \%$ 로 높은 수 행력을 보였으나, 브로카 실어증 환자군에서는 양순음 73.9 $( \pm 25.1) \%$, 치조음 $67.2( \pm 29.8) \%$, 경구개음 $72.7( \pm 31.8) \%$, 연 구개음 72.0( \pm 33.3$) \%$, 성문음 83.3( \pm 30.4)\%로 나타났으며, 모두 통계적으로 유의한 차이를 보였다 $(p<0.05)$. 성문음이 가장 수행력이 높았으며, 양순음, 경구개음, 연구개음, 치조음 순으로 치조음에서 가장 낮은 수행력을 보였다. 하지만, 브로카 실어증 환자군 내에서는 조음 위치 간 음소표상 부호화 수행력 에서 유의한 차이를 보이지 않았다. 따라서 본 연구에서는 브 로카 실어증 환자군이 청각적 변별능력은 보존되어 있는 반면, 말 산출운동능력과 관련된 조음 산출에 결함을 보이는 것으로 나타났다.

\section{단어 수준에서의 이름 대기 과제 시 조음 특성}

정상군과 브로카 실어증 환자군 간 단어 수준에서 음운표상 의 특성을 알아보기 위해 PK-WAB-R 검사도구 내 이름 대기 과제를 실시하였다. 먼저 단어 수준에서의 음운 오류 특성을 살 펴본 결과, 브로카 실어증 환자군에서 대치, 첨가, 생략 순으로 많은 오류를 보였으며 모두 통계적으로 유의미한 차이를 보였 다. 이는 Popovici \& Voinescu(1991)의 연구에서 실어증 환자 들에게 주로 보이는 음운 오류인 생략, 대치, 첨가 중에서 대치 를 가장 많이 보인다는 연구와 일치한다.

음운 단위에 따른 수행력을 비교해 본 결과, 정상군에서는 $100 \%$ 의 수행력을 보였다. 하지만 브로카 실어증 환자군에서는 자음 84.8( \pm 17.2$) \%$, 모음 93.0( \pm 6.57)\%로 나타났으며, 모음보 다 자음에서 오류를 더 많이 보였다. 하지만 실어증 환자군 내 에서는 모음과 자음의 수행력에 통계적으로 유의한 차이는 보 이지 않아, 정상인에 비해 브로카 실어증 환자들은 모음과 자음 간 음소표상 부호화 능력에 차이가 없이 음소표상의 결함을 보 였다.

음운 위치에 따른 수행력에서는 정상군은 모두 $100 \%$ 의 수 행력을 보였고, 브로카 실어증 환자군에서는 어두초성 84.8( \pm $22.7) \%$, 어중초성 86.1( \pm 30.9)\%, 어말종성 90.9( \pm 7.7)\%로 나 타났다. 어두초성, 어중초성, 어말종성 모두 통계적으로 유의미 한 차이를 보였으며, 어말종성, 어중초성, 어두초성 순으로 높 은 수행력을 보였고, 어두초성에서 가장 낮은 수행력을 보였다. 하지만 본 연구에서는 브로카 실어증 환자 군 내에서 음운 위 치 간 음소표상 수행력을 살펴본 결과, 어두초성에서 가장 수 행력이 낮았으나, 통계적으로 유의미한 차이는 보이지 않았다. 이는 브로카 실어증 환자들이 말 산출 시 단어의 첫 음절뿐 아
니라 중간, 끝부분의 음절 위치에 상관없이 조음점을 찾는 데 가장 큰 어려움을 보인다는 것을 시사한다.

\section{발성개시시작시간 특성}

VOT는 말 산출에 있어서 조음과 발성 간 상호 작용을 측정 할 수 있는 중요한 지표로서 많이 사용되어져 왔다. 발성 유형 별로 나누어 볼 때, 발성 유형 간 발성개시시작시간은 정상군과 비슷한 패턴을 보였다. 발성 유형별로는 평음, 경음, 격음 모두 정상군에 비해 길게 나타났으나, 경음에서만 통계적으로 유의미 한 차이를 보였다. 즉, 평음과 격음에서는 브로카 실어증 환자군 이 길게 나타났으나, 통계적으로 유의미한 차이는 없었고 $(p>$ $0.05)$ 경음에서는 브로카 실어증 환자군이 유의미하게 긴 VOT 를 보였다 $(p<0.05)$. 따라서 브로카 실어증 환자는 평음이나 격음에 비해 경음 산출에 더 어려움을 보이는 것으로 나타났다.

정상군과 브로카 실어증 환자군 간 조음 위치별 $\mathrm{VOT}$ 를 살펴 보았을 때, 연구개음에서만 브로카 실어증 환자군이 긴 VOT를 보였으나, 통계적으로 유의한 차이를 보이지 않았다 $(p>0.05)$. 마찬가지로 양순음과 치조음에서는 정상군에서 약간 높은 VOT 값을 보였으나, 통계적으로 유의미한 차이를 보이지 않았다.

실어증 환자군의 VOT 값을 연구한 Gandour \& Darddarananda(1984)와 Baum \& Rayn(1993)에 의하면, 브로카 실어 증과 전반 실어증 환자들이 베르니케 실어증, 전도 실어증, 연결 피질운동 실어증 환자보다 긴 VOT 값을 보였다고 하였다. 그러 나 본 연구에서는 브로카 실어증 환자들의 말소리를 발성 유형 별로 평음, 경음, 격음에서 모두 평균 $\mathrm{VOT}$ 가 길게 나타났으나, 경음에서만 통계적으로 유의미한 차이를 보였다. 또한 조음 위 치별로 살펴보았을 때, 연구개음에서 유의미하게 긴 VOT를 보 였다. 따라서, 브로카 실어증 환자는 발성과 조음 협응능력이 정상군에 비해 저하되어 있음을 시사한다. Kim et al.(2002)의 연구에서는 5 명의 비유창성 실어증 환자를 대상으로 파열음과 파찰음을 이용하여 VOT를 측정하였으며, 파열음에서는 의미 있는 단음절(/벌/, /닭/, /곰/)에서 조음 위치에 따른 비유창성 실어증 환자군과 정상군의 VOT 차이를 살펴보았는데, 양순음 과 연구개음의 VOT가 정상군에 비해 유의하게 길게 나타났으 나, 본 연구 결과와 차이를 보였다. 본 연구에 참여한 비유창성 실어증 환자는 경도에서 중도의 실어증 환자로서 말 자극어를 파열음으로 VOT를 살펴보는 것이 파열 이후 성대가 진동하기 시작하는 구간을 가장 잘 확인할 수 있다는 선행연구에 따라 (Ozsancak et al., 2001), 파열음만을 대상으로 VOT를 측정하 였으며 문맥의 영향을 최소화하기 위해 무의미음절(/아바/, /아 빠/, /아파/, /아다/, /아따/, /아타/, /아가/, /아까/, /아카/)에서 측 정하였기 때문에 위의 결과와 차이가 있는 것으로 보인다.

본 연구 결과 비유창성 브로카 실어증 환자는 무의미음절 수 
준에서 음소 지각에는 별 어려움을 보이지 않았으나 음소 산출 에 어려움을 보였다. 즉, 발성 유형이나 조음 위치에 따른 자음 변별은 정상 화자와 유의미한 차이를 보이지 않았으나, 발성 유 형이나 조음 위치, 조음 방법에 따른 조음 오류를 보였다. 또한 브로카 실어증 환자의 파열음의 조음 위치와 발성 유형에 따른 VOT는 정상 화자와 비슷한 양상을 보였으나, 발성 유형에 있어 서는 정상 화자와 차이를 보였다. 이러한 결과는 브로카 실어증 환자들이 정상 화자에 비하여 후두의 조절능력 저하 및 후두 와 조음기관의 협응능력의 저하와 같은 말 통제조절능력의 저 하와 관련 있을 수 있음을 시사한다.

본 연구의 제한점과 후속연구를 위한 제언은 다음과 같다. 첫째, 본 연구에 참여한 대상자의 성별은 남성이 대부분이었다. 추후 연구에서는 성비를 균등하게 하거나 여성으로 이루어진 정상군과 브로카 실어증 환자군들을 대상으로 비교해 볼 것을 제안한다. 둘째, 본 연구에 참여한 대상자의 수는 적은 인원을 대상으로 하여, 통계적으로 의미 있는 결과를 도출하기에 어려 움이 컸다. 후속연구에서는 많은 인원을 대상으로 후속연구를 진행해 볼 것을 제안한다. 셋째, 본 연구에서는 브로카 실어증 환자군의 실어증 지수(Aphasia Quotient)를 중증도별로 나누 지 못하였다. 추후 연구에서는 환자군의 중증도를 세분화하여 비교해 볼 것을 제안한다. 넷째, 본 연구에서는 브로카 실어증 과 성과 연령을 일치시킨 정상군을 비교하였으나, 추후의 연구 에서는 다른 유형의 실어증과 비교하여 조음능력을 살펴볼 것 을 제안한다.

중심 단어 : 브로카 실어증·말 통제조절능력·자음 변별·

$$
\text { 음소표상·조음. }
$$

\section{REFERENCES}

Bae, J. A. (2005). A comparative study for the production of content words and function words in Broca aphasics. Communication Sciences and Disorders, 10(2), 12-31.

Banich, M. T., Compton, R. J. (trans. Kim, M. S., Kang, E. J., Kang, Y., \& Kim, H. T.) (2014). Cognitive Neuroscience. Seoul: Pakhaksa.

Baum, S. R., Blumstein, S. E., Naeser, M. A., \& Palumbo, C. L. (1990). Temporal dimensions of consonant and vowel production: An acoustic and CT scan analysis of aphasic speech. Brain and Language, 39(1), 33-56.

Baum, S. R. \& Ryan, L. (1993). Rate of speech effects in aphasia: Voice onset time. Brain and Language, 44(4), 431-445.

Davis, G. A. (2000). Aphasiology: Disorders and Clinical Practice. Boston, MA: Allyn \& Bacon.

Gandour, J. \& Dardarananda, R. (1984). Voice onset time in aphasia: Thai. II. Production. Brain and Language, 23(2), 177-205.

Huber, W., Poeck, K., \& Weniger, D. (1997). Aphasie. In Hartje, W. \& Poeck,
K. Klinische Neuropsychologie. Stuttgart: Thieme.

Hwang, M. (2002). Sentence comprehension of Korean-speaking adults with Broca's aphasia. Communication Sciences and Disorders, 7(2), 6585.

Kang, Y. W., Chin, J. H., Na, D. L., Lee, J. H., \& Park, J. S. (2000). A normative study of the Korean version of Controlled Oral Word Association Test (COWAT) in the elderly. Korean Journal of Clinical Psychology, 19(2), 385-392.

Kim, H. G., Kang, E. Y., \& Kim, Y. H. (2002). An acoustic analysis of speech in patients with nonfluent aphasia. Speech Science, 9(3), 87-97.

Kim, H. H. (2012). Neurologic Speech-Language Disorders. (1st ed.). Seoul: sigmapress.

Kim, H. H. \& Na, D. L. (2012). Paradise.Korean Version-Western Aphasia Battery. (2nd ed.). Seoul: Paradise.

Kim, N. Y. \& Ha, J. W. (2014). Phonologicl representations in children with articulation and phonological disorders. Communication Sciences and Disorders, 19(2), 226-237.

Kim, S. R., Park, C. I., Kim, D. Y., \& Hwang, M. A. (2004). Production of nouns and verbs in adults with Broca's aphasia: Comparison between naming and narration. Communication Sciences and Disorders, 9(2), 1-18.

Korea National Statistical Office. (2016, September 27). Cause of Death Statistics in 2015. Statistics Korea. Retrieved from http://kostat.go.kr/portal/korea/kor_nw/2/6/2/index.board?bmode=read\&aSeq=356345.

Kwon, M. (2004) Evolution of aphasia profile and auditory comprehension ability in Wernicke's aphasia (doctoral dissertation). Ewha Womans University, Seoul.

Magnúsdóttir, S. \& Thráinsson, H. (1990). Agrammatism in Icelandic: Two case studies. In Menn, L. \& Obler, L. K. Agrammatic Aphasia: A CrossLanguage Narrative Sourcebook, Vol. 1. Amesterdam: John Benjamins.

McNeil, M. R. (1984). Current concepts in adult aphasia. International Rehabilitation Medicine, 6(3), 128-134.

Miceli, G., Gainotti, G., Caltagirone, C., \& Masullo, C. (1980). Some aspects of phonological impairment in aphasia. Brain and Language, 11(1), 159169.

Ozsancak, C., Auzou, P., Jan, M., \& Hannequin, D. (2001). Measurement of voice onset time in dysarthric patients: Methodological considerations. Folia Phoniatrica et Logopaedica, 53(1), 48-57.

Popovici, M. \& Voinescu, I. (1991). Type and frequency of phomemic errors in aphasics. Revue Roumaine de Neurologie et Psychiatrie, 29(3-4), 183195.

Ryalls, J., Provost, H., \& Arsenault, N. (1995). Voice onset time production in French-speaking aphasics. Journal of Communication Disorders, 28(3), 205-215.

Shewan, C. M., Leeper, H. A., \& Booth, J. C (1984). An analysis of voice onset time (VOT) in aphasic and normal subjects. In Rosenbek, J. C., McNeil, M. R., \& Aronson, A. E. (1st ed.). Apraxia of Speech: Physiology, Acoustics, Linguistics, Management. San Diego, CA: College-Hill Press.

Stark, J. A. \& Dressler, W. U. (1990). Agrammatism in German: Two case studies. In Menn, L. \& Obler, L. K. Agrammatic Aphasia: A Cross-Language Narrative Sourcebook, Vol. 1. Amesterdam: John Benjamins.

Tomer, R. \& Levin, B. E. (1993). Diffrential effects of aging on two verbal fluency tasks. Perceptual and Motor Skills, 76(2), 465-466.

Yorkston, K. M. \& Beukelman, D. R. (1980). An analysis of connected speech sample of aphasic and normal speakers. Journal of Speech and Hearing Disorder, 45, 27-36. 


\section{APPENDICES}

Appendix 1. 음소 변별 과제 검사지
1. 생년월일:
2. 생활연령:
3. 이름(성별):

*정반응: 1점, 오반응: 0점

\begin{tabular}{|c|c|c|c|c|}
\hline 문항 & \multicolumn{2}{|c|}{ 변별 자음 } & 반응 & 정/오 \\
\hline 1 & 마 & 나 & & \\
\hline 2 & 라 & 라 & & \\
\hline 3 & 다 & 라 & & \\
\hline 4 & 다 & 가 & & \\
\hline 5 & 빠 & 빠 & & \\
\hline 6 & 짜 & 짜 & & \\
\hline 7 & 다 & 타 & & \\
\hline 8 & 가 & 바 & & \\
\hline 9 & 하 & 자 & & \\
\hline 10 & 나 & 나 & & \\
\hline 11 & 마 & 라 & & \\
\hline 12 & 바 & 사 & & \\
\hline 13 & 차 & 차 & & \\
\hline 14 & 싸 & 싸 & & \\
\hline 15 & 라 & 나 & & \\
\hline 16 & 자 & 자 & & \\
\hline 17 & 카 & 카 & & \\
\hline 18 & 다 & 사 & & \\
\hline 19 & 사 & 나 & & \\
\hline 20 & 다 & 다 & & \\
\hline
\end{tabular}

\begin{tabular}{|c|c|c|c|c|}
\hline 문항 & \multicolumn{2}{|c|}{ 변별 자음 } & 반응 & 정/오 \\
\hline 21 & 사 & 사 & & \\
\hline 22 & 가 & 가 & & \\
\hline 23 & 바 & 다 & & \\
\hline 24 & 바 & 빠 & & \\
\hline 25 & 바 & 바 & & \\
\hline 26 & 하 & 하 & & \\
\hline 27 & 자 & 마 & & \\
\hline 28 & 차 & 짜 & & \\
\hline 29 & 하 & 하 & & \\
\hline 30 & 파 & 파 & & \\
\hline 31 & 바 & 마 & & \\
\hline 32 & 타 & 타 & & \\
\hline 33 & 가 & 나 & & \\
\hline 34 & 다 & 다 & & \\
\hline 35 & 가 & 가 & & \\
\hline 36 & 마 & 마 & & \\
\hline 37 & 사 & 싸 & & \\
\hline 38 & 사 & 하 & & \\
\hline 39 & 자 & 자 & & \\
\hline 40 & 가 & 카 & & \\
\hline & & & 총점 & \\
\hline
\end{tabular}


Consonant Discrimination and Articulation in Broca's Aphasia

Appendix 2. Korean Western Aphasia Battery 이름 대기 과제 검사지

1. 생년월일:

2. 생활연령:

3. 이름(성별):

\begin{tabular}{|c|c|c|c|c|c|}
\hline \multicolumn{2}{|r|}{ 자극물 } & 반 응 & 의미 단서 (15초 경과 후 제시) & 반 응 & 1음절 단서 후 반응 \\
\hline 1 & 책 & & 도서관에 있는 것 & & \\
\hline 2 & 공 & & 축구, 야구 등을 할 때 사용하는 것 & & \\
\hline 3 & 가위 & & 종이를 자를 때 사용하는 것 & & \\
\hline 4 & 컵 & & 물을 따라마실 때 사용하는 것 & & \\
\hline 5 & 손톱깎이 & & 신체의 일부를 정리할 때 사용하는 도구 & & \\
\hline 6 & 망치 & & 못을 박을 때 사용하는 것 & & \\
\hline 7 & 숟가락 & & 밥이나 국을 먹을 때 사용하는 것 & & \\
\hline 8 & 안경 & & 눈이 나쁘면 써야 하는 것 & & \\
\hline 9 & 자물쇠 & & 물건을 보관하고 잠글 때 사용하는 것 & & \\
\hline 10 & 연필 & & 필기할 때 쓰는 것 & & \\
\hline 11 & 거울 & & 얼굴을 볼 수 있는 것 & & \\
\hline 12 & 열쇠 & & 문이 잠겼을 때 열 수 있는 것 & & \\
\hline 13 & 胘 & & 열매가 열리기 전에 피는 것 & & \\
\hline 14 & 시계 & & 시간을 알 수 있는 것 & & \\
\hline 15 & 빗 & & 머리카락을 정리할 때 사용하는 것 & & \\
\hline 16 & 고무줄 & & 잡아당기면 늘어나는 것 & & \\
\hline 17 & 칫솔 & & 양치할 때 필요한 것 & & \\
\hline 18 & 딸기 & & 과일의 일종 & & \\
\hline 19 & 젓가락 & & 반찬 집을 때 사용하는 것 & & \\
\hline 20 & 호두 & & 견과류의 일종 & & \\
\hline & & & 총 & & \\
\hline
\end{tabular}

